\title{
Arabic Dialects of Lamomea and Pudahoa at Students in Gontor 4 and 7 Southeast Sulawesi
}

\author{
Laode Abdul Wahab ${ }^{1}$, Aris Try Andreas Putra ${ }^{2}$ \\ Institut Agama Islam Negeri Kendari, Indonesia \\ Email Correspondence: abdulwahablaode@gmail.com
}

\begin{abstract}
Background:

The symptom of using two languages in the local dialect of the Arabic speaking community in Southeast Sulawesi can be seen as an interesting phenomenon. This study aims to identify and reveal: (1) The Arabic language of local dialect "Pudahoa" at Pondok Putra 7 and "Lamomea" at Gontor Putri 4 in Southeast Sulawesi; (2) Coding variations in the communication of Arabic language in the local dialects of Lamomea and Pudahoa; and (3) the use of local Arabic dialects of Lamomea and Pudahoa.
\end{abstract}

\section{Methodology:}

This research was conducted in the speaking community of Southeast Sulawesi who uses the local Arabic dialect located in Konawe Selatan at two focuses: (1) Arabic Lamomea; and (2) Arabic Pudahoa speaking community. The method used in this research is descriptive method qualitative. The descriptive method is an attempted research method to describe and interpret objects according to the circumstances.

Findings:

This study found: first, the Arabic variation used in social interactions in Gontor Putri 4 is Arabic in the Lamomea dialect. Meanwhile, the Arabic variation used in social interactions in Gontor Putri 7 is Arabic in the Pudahoa dialect. The variations of code-switching that occur in the speech communities of Gontor Putri 4 and Gontor Putra 7 with the linguistic repertoire that exists in the community include first, code-switching in the form of language translation and second, code-switching in the form of speech level code-switching. Furthermore, the codes found in Arabic spoken by the Gontor Putri 4 and Putra 7 speaking community are in the form of phrases. Mix this code in the form of an Indonesian phrase into a sentence or speech. Lamomea and Pudahoa dialect Arabic as a subordinate standard language have several functions. Third, the use of Arabic in the local dialects of Lamomea and Pudahoa consists of the formal domain, kinship domain, religious domain, transactional use, social environment, informal environment, and non-formal domain.

\section{Conclusion:}

There are variations of code-switching, and code-mixing in the Arabic speech communities of Lamomea and Pudahoa, Tthe Lamomea and Pudahoa dialects have local and regional characteristics and functions as a means of internal communication, a symbol of community identity and as a means of communication in formal, informal and non-formal situations. The author hopes that there will be further research that focuses on how patterns of influence between Arabic and local culture.

Keywords: Arabic language form; coding variations; the dialect use.

DOI $\quad:$ http//dx.doi.org/10.24903/sj.v5i2.495

\begin{tabular}{|l|l|l|}
\hline Received & $:$ & August 2020 \\
\hline Accepted & $:$ & September 2020 \\
\hline Published & $:$ & October 2020 \\
\hline Copyright Notice & $:$ & $\begin{array}{l}\text { Authors retain copyright and grant the journal right of first publication with the } \\
\text { work simultaneously licensed under Creative Commons Attribution 4.0 International } \\
\text { License that allows others to share the work with an acknowledgement of the work's }\end{array}$ \\
\begin{tabular}{ll} 
authorship and initial publication in this journal. \\
\hline
\end{tabular}
\end{tabular}

\section{INTRODUCTION}

Dialectology is a sociolinguistic sub-field concerning dialects or language variations in a community. Dialects study the elements of grammar, lexicon, and phonology in an area. 
Therefore, this field does not only examine people living in an area for generations but also groups of migrants who bring their language to a new area (language contact).

The problem of using language as the focus of this study can be viewed as a social problem commonly faced by bilingual or multilingual societies. This gesture has been reviewed for a long time, indicating that the use of a language is related to the socio-cultural values of a society (Fasold, 1991; Ma'u et al., 2019). The sociological approach appears in the analysis of the social domain of language use. However, this study still refers to the ethnographic model of communication (Fajaruddin, 2011; Hymes, 2003) which addresses the phenomenon of using mixed languages as a communication event and becomes an evidence of the social and cultural identity of the speech participants.

Several studies on the dialect of the archipelago have been widely carried out, but most of them are carried out in the context of dialectological research which is more about synchronic and diachronic descriptions of language. Several studies related to the problem of codes and greeting systems in foreign languages have been developed in speaking communities in Indonesia. Research conducted by Zaini (2010) for example, reports the communicative code, the semantic changes occur amongst santris seem to be influenced by their first language or their mother tongue.

Furthermore another researcher, Sutarsih (2016) who studied of code-mixing in Pekojan, Semarang. The code-mixing Code-mixing in Pekojan kampong occurs at the level of words in the form of blending Indonesian words with Arabic, Javanese and Betawi language. The code-mixing between Indonesian, Arabic, and Betawi language is done by those who have a high social relationship with different ethnic communities in their environment. Code-mixing using Javanese as the native language of indigenous peoples of Pekojan kampong is only performed by the elderly. Similarly, code-mixing with the Betawi language is only used by the elderly of Arab descent people.

Furthermore, Kurniasih and Zuhriyah (2017) who studied the code-switching and codemixing coding in Gontor found there were code-mixing and code-switching in the form of Javanese and Indonesian due to the ineffective use of foreign languages by the students. The factors that cause code-switching and code-mixing are: (1) the habit of using regional languages; (2) Departmental policies in the cottage environment; (3) speaker; (4) the topic or subject caused by the language factor itself; (5) situation; and (6) social languages.

Research related to language choice was also carried out by Wahab (2012). It was found that variations in speech community communication coding in Empang Bogor include a single variation of Arabic, Indonesian, and Sundanese. Language contact is unavoidable so 
that speakers often do code-switching and code-mixing. The results indicate that the language used in the community of Arabian in Empang Bogor had different functions and roles related to social, cultural, and situational factors. Similarly, Wahab (2015) highlights that several variations of language happened at Baruga traditional market, especially the variation of local languages such as Indonesian, Javanese, Tolaki, Bugis, Makassarnese, Sundanese, Munanese, Wawonii, Ereke, Ambonese, and Wakatobi. Then there were 20 variations of code-switching and other variations of code-mixing. The results of this study indicate language contact in the Baruga market speaking community in Kendari. Wahab's research just explains how the variations of the communication code for the Baruga market speech community in Kendari City include a single variation of language consisting of eleven local languages, namely Indonesian, Javanese, Tolaki, Bugis, Makassarese, Sundanese, Muna, Wawonii, and Ereke, Ambonese language, Wakatobi language. While this research will explain how codeswitching and speech community code-mixing in pesantren Gontor 4 and 7, are examining: (1) Arabic local dialects; (2) coding variation in the communication; and (3) The use of local Arabic dialects of Lamomea and Pudahoa.

In other research, Aviah et al. (2019) researched Change of Code Mixing Codes and Changes in Meaning of Integration of Arabic in Indonesian in the Film "Sang Kiai" (Sociolinguistic Analysis). He founds the following conclusions: there were 13 codeswitching speeches with external code-switching types and seven code-mixed speeches with outer code-mixing types. In 13 speech events where code-switching was indicated, there were 12 code-switching in the form of sentences (number) with details of 7 code-switching with the number of "ismiyah", four code-switching in the form of "fi'liyah" number, one codeswitching in the form of "syartiyyah" number, and one code-switching in the form of discourse. Meanwhile, in mixing the code several 7 data were found, one mixed code in the form of sentences (words), two mixed codes in the form of murakkab ismiy, one mixed code in the form of murakkab jaariy, three mixed codes in the form of murakkab mashdariy. Several factors cause code-switching and code-mixing. From the results of the research that has been carried out, several causes of code-switching have been found, of the 13 speeches indicated by code-switching, 2 of which were caused by speaker factors, 4 of them were caused by the interlocutor factor, three were caused by the changing situation due to the presence of a third person, and 4 of them were caused by changes in the topic of conversation, whereas in the film Sang Kiai, it is not found for factors that cause changes from formal to informal. 
Sociolinguistics examines language associated with its social context so that Pride and Holmes (1972) calls sociolinguistics as the study of language as part of culture and society. Here there is an affirmation that language is part of the culture, not something that stands alone. Language lives and develops in society even though people are not fully aware of it, including the use of Arabic in certain speaking communities. The use of Arabic, which has a wide area, is also influenced by the environment, such as in politics, local culture, natural environment, and local languages. According to Ferguson (1997), the wide area of Arabic language use is one of the causes of the variations of Arabic dialects.

Furthermore, Wafistates that the emergence and development of Arabic dialects are caused by several factors, namely: (1) Arabic is spread in non-Arabic environments; (2) Socio-political factors, new state fragments appear; (3) Differences in community rules, customs, knowledge; (4) Hereditary factors; (5) Differences in speech tools; (6) Changes in the meaning of words; (7) Changes in the meaning of words for each generation; (8) Changes in the meaning of words due to changes in function; (9) Changes in the final sound of words; (10) The entry of new words; (11) The entry of new sounds; (12) The entry of new grammar; (13) The loss of words due to not being used until they are pronounced heavy. Symptoms of the use of two languages in the local dialect Arabic speaking community in the speech community in Southeast Sulawesi when referring to Ferguson's idea is considered interesting since the people derived the language from the Arabic language as mentioned in this research background.

The use of local Arabic dialect by the local community (pesantren students) does not only illustrate the strong interplay between Arabic and local languages, so that language contact occurs but more than that this phenomenon is important to trace to identify the sociological facts of Arabic that can adapt to local language culture or otherwise. In the case of Southeast Sulawesi, this phenomenon is sociologically possible because this area is inhabited by speakers of very diverse local languages based on regional distribution and above $90 \%$ are Muslims, which means that at certain times use Arabic in their communication.

The observation involved the author, finding several phenomena of the use of local dialect Arabic, such as

Example (1) speech in the market:

Speaker A. : ilaaaina anti, $\boldsymbol{k} \boldsymbol{a}$ (where are you going, ka)

Speaker B : ilalma'kuulaaat, ji (to the food stall, ji)

Example (2) speech on buying and selling:

Speaker A : madza isytaroyti, $\boldsymbol{k a}$ (what have you bought, ka) 
Speaker B : isytaroytu laban, ji (i have bought milk, ji)

Based on the above example, speaker A added the particle $k a$ in the sentence ilaaaina $a n t i, k a$, when speaker A asked where the speaker B was going. Likewise, with example (1) speaker B added the particle $j i$ in the sentence ilalma 'kuulaaat, $j i$. The addition of $k a$ and $j i$ particle is a local linguistic phenomenon and becomes an uptake of Arabic because of the contact between Arabic and local languages. This case is often used by certain speech communities in Kendari, especially in Lamomea.

The phenomenon of mixing the local and Arabic dialect in a certain speaking community in Southeast Sulawesi referring to what Ferguson (1989) saidis an interesting phenomenon especially with the inclusion of some particles in Arabic utterance as explained above. Based on the previous explanation, this study aims to examine: (1) local Arabic dialects of "Pudahoa" at Pondok Putra 7 and "Lamomea" at Gontor Putri 4 in Southeast Sulawesi; (2) coding variation in the communication for local Arabic dialects of Lamomea and Pudahoa; and (3) The use of local Arabic dialects of Lamomea and Pudahoa.

\section{METHODOLOGY}

This research uses a qualitative research method with a type of case study in which this research analyzes the facts obtained to examine the origin of the use of Arabic dialectology in the Arabic speech communities in Lamomea and Pudahoa. The respondents in this study were students and religious teachers. Respondents were chosen purposefully. The sociocultural background of students and ustadz are active Arabic speech participants. This study was located in two districts in Southeast Sulawesi; namely Konawe Selatan at the Gontor Putri 4 boarding school and Gontor Putra 7.

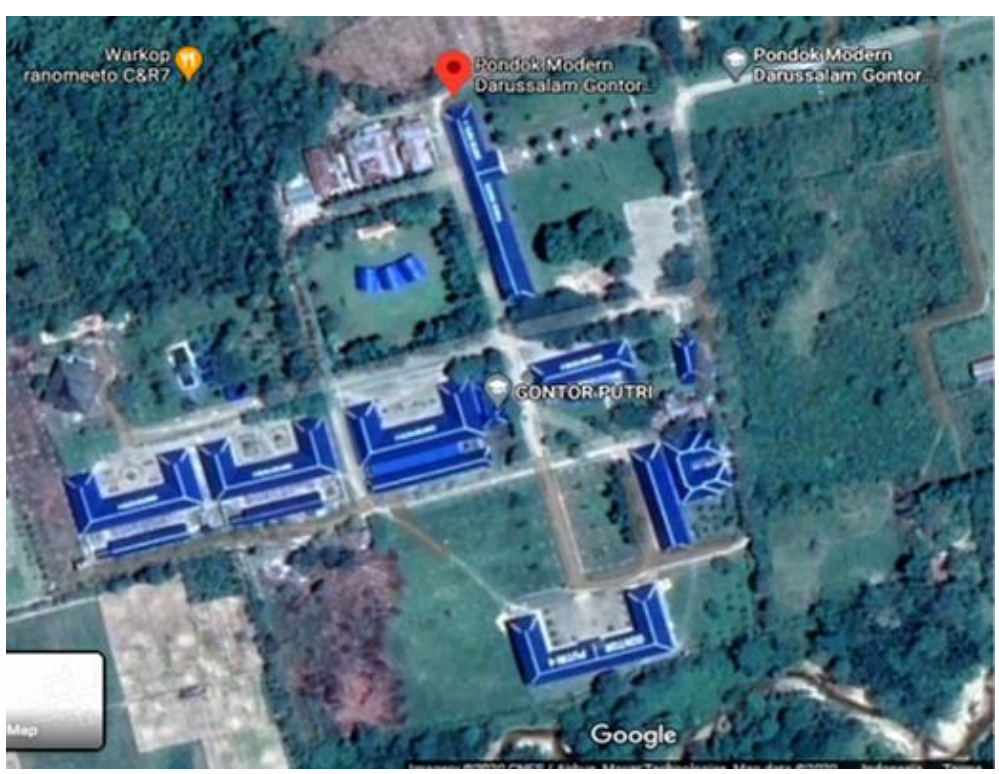

Figure 1. Gontor Putri 4 boarding school 


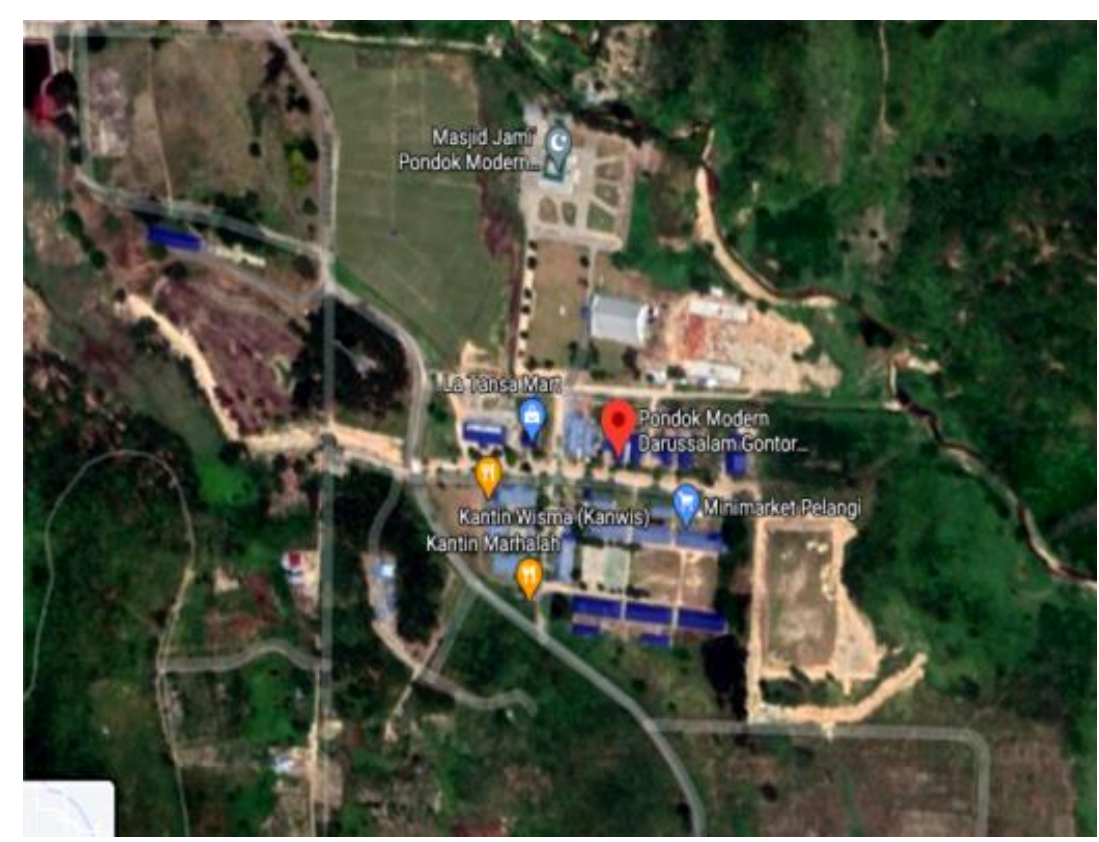

Figure 2. Gontor Gontor Putra 7 boarding school

The data were collected by using field notes and recordings. All data collected were then transcribed, classified, and linguistically categorized. After that, the researchers conclude and determine the research questions. To analyze the data, the researchers carried out two important procedures, such as (1) analyze the data in the data collection process, and (2) analyze the data once all data collection process is complete. The research design flow chart as follows:

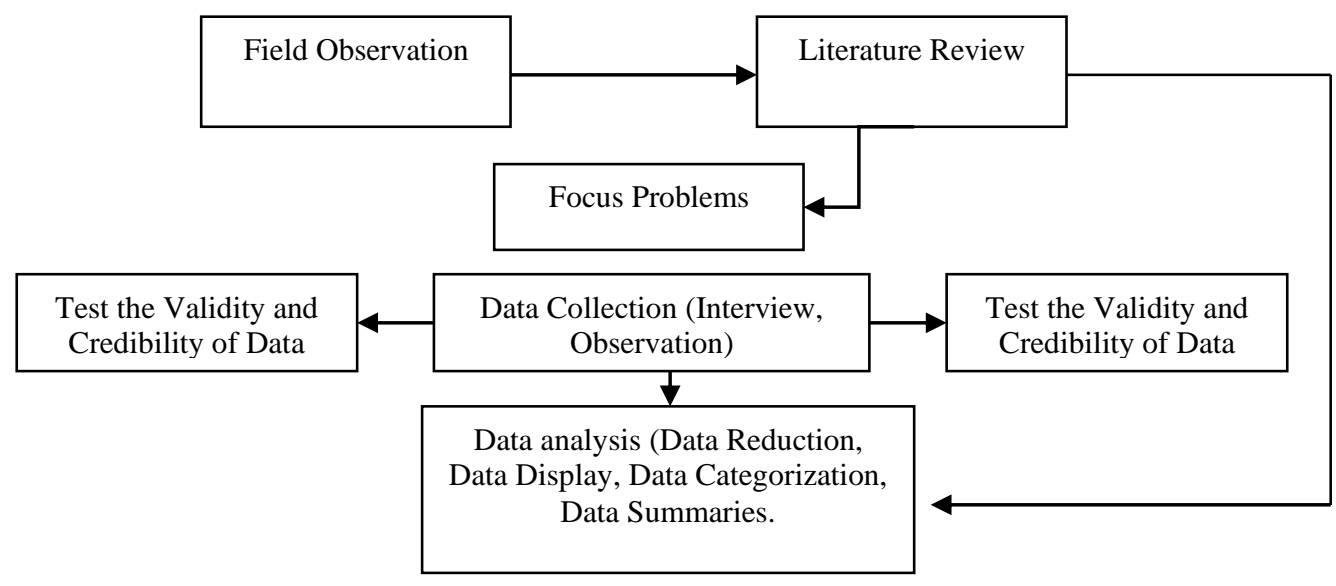

Figure 3. The Research Design Flow Chart

The first procedure is carried out by the following steps: (a) data reduction, namely identifying the form of language choice, the diversity of code choices in the social sphere, language relations with culture as well as the social and religious settings of the speech events and speech components, (b) presenting data (data display) with a matrix image pattern; and (c) taking tentative conclusions/verification to be verified, either by triangulating data or by triangulating data collection techniques. This step of the analysis process by Miles and 
Huberman (1992) is called an interactive model analysis. The second procedure is carried out by the following steps: (a) transcription of the recorded data; (b) grouping or categorizing data originating from recording and field notes based on the identification of the preferred language form, (c) interpretation of the use of Arabic local dialects of Southeast Sulawesi, and (d) concluding the use of code in speaking local communities in Southeast Sulawesi.

\section{FINDINGS}

\subsection{Local Arabic Dialects of Lamomea and Pudahoa}

Table 1. Changes in Arabic variations in the Lamomea and Pudahoa dialects

\begin{tabular}{|c|c|c|c|c|}
\hline No. & $\begin{array}{l}\text { Arabic } \\
\text { script }\end{array}$ & Transliteration & $\begin{array}{c}\text { Lamomea and Pudahoa } \\
\text { Arabic speech }\end{array}$ & Addition of Lamomea and Pudahoa dialects \\
\hline 1. & 1 & A & $\mathrm{A}$ & mi, ji, to, pale, na, kah. As in the example in \\
\hline 2. & ب & $\mathrm{Ba}$ & $\mathrm{Ba}$ & lamomea: isytaroytulaban, ji \\
\hline 3. & $ت$ & $\mathrm{Ta}$ & $\mathrm{Ta}$ & \\
\hline 4. & $\dot{H}$ & Tsa & Tsa & \\
\hline 5. & 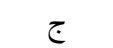 & $\mathrm{Ja}$ & $\mathrm{Ja}$ & \\
\hline 6. & $\tau$ & $\mathrm{Ha}$ & $\mathrm{Ha}$ & \\
\hline 7. & $\dot{\tau}$ & Kha & Kha & \\
\hline 8. & د & $\mathrm{Da}$ & $\mathrm{Da}$ & \\
\hline 9. & $\dot{j}$ & Dza & Dza & ee, mi, ji, to, pale, nah \\
\hline 10. & J & $\mathrm{Ra}$ & $\mathrm{Ra}$ & \\
\hline 11. & j & Dza & Dza & example in Pudahoa: \\
\hline 12. & س س & $\mathrm{Sa}$ & $\mathrm{Sa}$ & intadzirna \\
\hline 13. & 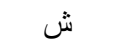 & Sya & Sya & \\
\hline 14. & ص ص & Sha & Sha & \\
\hline 15. & 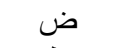 & Dha & Dha & \\
\hline 16. & b & Tha & Tha & \\
\hline 17. & ظ & Zha & Zha & \\
\hline 18. & $\varepsilon$ & $A^{\prime}$ & $A^{\prime}$ & \\
\hline 19. & $\dot{\varepsilon}$ & Gha & Gha & \\
\hline 20. & ف & $\mathrm{Fa}$ & $\mathrm{Fa}$ & \\
\hline 21. & 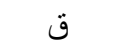 & Qa & Qa & \\
\hline 22. & ك5 & $\mathrm{Ka}$ & $\mathrm{Ka}$ & \\
\hline 23. & ل & $\mathrm{La}$ & $\mathrm{La}$ & \\
\hline 24. & 3 & Ma & Ma & \\
\hline 25. & ن & $\mathrm{Na}$ & $\mathrm{Na}$ & \\
\hline 26. & g & Wa & $\mathrm{Wa}$ & \\
\hline 27. & 。 & $\mathrm{Ha}$ & $\mathrm{Ha}$ & \\
\hline 28. & 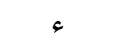 & A & A & \\
\hline 29. & ي & $\mathrm{Ya}$ & $\mathrm{Ya}$ & \\
\hline
\end{tabular}

Arabic language in the Lamomea and Pudahoa dialects addressed in this study is the variations of Arabic and local dialects in some language events at Gontor Putri 4 and Gontor Putra 7 of Islamic Boarding School. The social identity of the language "Lamomea" refers to a reference or geographic attribute of the government area called Lamomea Village, where Pondok Pesantren Gontor Putri 4 carries out language activities. Whereas the mention of the social identity of the language "Pudahoa" refers to a reference or geographic attribute of the government area called Pudahoa Village where the Gontor Putra 7 Islamic Boarding School 
carries out linguistic activities. In the following, we will describe the changes in the variations of the Arabic dialects of Lamomea and Pudahoa as in the Table 1.

\subsection{Coding variation in the communication for local Arabic dialects of Lamomea and Pudahoa}

3.2.1 The single variation form of the Lamomean Language

The variation of Arabic used in social interactions at Gontor Putri 4 is Arabic in the Lamomea dialect. As a communication tool for Arabic, the Lamomea dialect is one of the standard Arabic dialects with its position as a subordinate of the standard language. Its distinctive characteristics are caused by regional factors. According to a linguistic perspective, the Arabic language of the Lamomea dialect has the same position as the Arabic language of the fushah and ammiyah varieties developed in various regions that use these two languages. The Arabic language of the Lamomea dialect as a subordinate of the standard language has several functions, namely: (1) as an internal communication tool in the Gontor Putri speaking community, (2) as a symbol of the identity of the local community, (3) as a means of communication in formal, informal and non-formal situations.

As an internal communication tool, Arabic in the Lamomea dialect is a common communication tool in the community as reported at Gontor Putri 4. Some speaking groups, especially those who are still loyal to Arabic in the Lamomea dialect, continue to use it in their communities. Arabic as a symbol of the identity of the local community, characterizes that the Lamomea dialect can distinguish it from other dialects. In formal situations, Arabic in the Lamomea dialect is used in the classroom in learning activities, teacher and student interactions, media and learning resources. Outside the class, the activities of ilqo mufrodat, speeches, debates, teacher, and students' interactions, Kutaib, TV, mufrodat tempel. Meanwhile, the administrative system is in the form of announcements, correspondence and the committee, diplomas and certificates, and evaluation instruments. In informal situations, this dialect is used in the family, religious and transactional uses. In non-formal situations, the Lamomea dialect is used in young learner classes, halal bi halal, new student graduations and performing arts. The following is an example of a speech event in the Lamomea dialect of Arabic:

Example (1) speech used in the sales process:

Speaker A. : MadzaIsytaroyti, huh (what have you bought, huh)

Speaker B : isytaroytukahwa, ji (I have bought coffee, ji) 


\subsubsection{Lamomea Code Transfer Variation Form}

The result of bilingualism can be divided into three types, namely: social, cultural, and linguistic consequences. The social impact starts from the background of the speech participants' social life; cultural consequences depart from the different cultures of the speech participants. Meanwhile, the linguistic result of the mastery of two or more languages possessed by the speech participants, in this case, the community of Gontor, causes codemixing, code-switching and borrowing. Code mixing occurs whether they use Arabic, English, Indonesian, Javanese, Tolakinese or Buginese.

Another result of mastering two or more language is code-switching. Code-switching is the process of moving someone from one code to another or from one language to another. Code-switching occurred in the Gontor Putri speech community is in the form of codeswitching from Arabic to English, Arabic to Indonesian, Arabic to Javanese, Arabic to Tolaki, Arabic to Bugis, English to Arabic, Indonesian to Arabic, Javanese to Arabic, Tolaki to Arabic, Bugis to Arabic, and vice versa as well as code-switching from one variety to another, namely the fushah variety to the ammiyah variety.

The variations of code-switching that occur in the Gontor Putri speech community with the linguistic repertoire available in the community include: first, code-switching in the form of language translation and second, code-switching in the form of speech level codeswitching. The first type of code transfer includes: (1) from Arabic to English, (2) Arabic to Indonesian, (3) Arabic to Javanese, (4) Arabic to Tolaki, (5) Arabic to Bugis, (6) English to Arabic, (7) Indonesian to Arabic, (8) Javanese to Arabic, (9) Tolaki to Arabic, (10) Buginese to Arabic. The second type of code transfer includes: (1) from Arabic fushah to Arabic ammiyah and vice versa. Likewise, with Arabic fushah to other languages and vice versa.

\subsubsection{Lamomea Code Mix Variation Form}

Code mixing is the use of two or more languages by inserting one language element into another which is used consistently. Code mixing carried out by the Gontor Putri speech community can be differentiated into code-mixing: (1) in the form of words, (2) in the form of phrases, (3) in the form of the baster, (4) in the form of elements of repetition, and (5) in the form of expressions or idioms.

The form of this mixed code in the form of words is determined by paying attention to the form of the lexicon used for Arabic speaking people. If in the Arabic speech there is another language lexicon that has an Arabic lexicon view, it means that in the speech there is a mixed code, namely the speech spoken by the Gontor Putri speech community in which there is a 
mixed code speech in the form of words and baster. The codes found in Arabic spoken by the Gontor speech community were in the form of phrases. Mix this code in the form of Indonesian phrases into sentences or language spoken. In Arabic spoken by the Gontor speech community, there is also a code mix in the form of a repetition element.

\subsubsection{The single variation form of the Pudahoa dialects}

The Arabic variation used in social interaction in the Gontor Putra speech community is Arabic in the Pudahoa dialect. Pudahoa Arabic dialect is the same as the Lamomea dialect. As a means of communication in Arabic, the Pudahoa dialect is one of the standard Arabic dialects with its position as a subordinate of the standard language. Its distinctive characteristics are caused by regional factors. According to a linguistic perspective, the Pudahoa dialect Arabic has the same position as the fushah and ammiyah Arabic languages that have developed in various regions that use these two languages. Pudahoa dialect Arabic as a subordinate standard language has several functions, namely: (1) as a means of internal communication in the community, Gontor Putra said, (2) as a symbol of the identity of the local community, (3) as a means of informal communication situations.

As an internal communication tool, Pudahoa dialect Arabic is a common communication tool in the community, said Gontor Putra. Various layers of speakers, especially those who are still loyal to Arabic, the Pudahoa dialect, continue to use it in their communities. Arabic as a symbol of the identity of the local community, indicates that the Pudahoa dialect can distinguish it from other dialects. In formal situations, Pudahoa dialect Arabic is used in the classroom realm in learning activities, teacher and student interactions, media and learning resources. Outside the class, the activities of ilqomufrodat, speeches, debates, student-teacher interaction, Kutaib, TV, mufrodattempel. Meanwhile, the administrative system is in the form of announcements, correspondence and the committee, diplomas and certificates, and evaluation instruments. In informal situations, this dialect is used in the family, religious and transactional realms. In non-formal situations, the Pudahoa dialect is used in family or relatives gathering, the graduation of new students and performing arts.

The following is an example of a speech event in the Pudahoa Arabic dialect:

Example (1) speech in the family domain:

Speaker A: Mobiluhu man? (whose car is that?)

Speaker B: lii (It is mine)

Other examples (2):

Penutur A: man haris mantiqo ee? (who is the picket boarder ee?) 
Penutur B: la arif ee ? (I don't know ee)

\subsubsection{Pudahoa Code Transfer Variations}

(Mustikawati, 2014) explained that a code-switching is a transition event from one code to another. If a speaker initially uses code A (for example Indonesian), then switches to using code B (for example Javanese), then a language switching event like this is called codeswitching. The result of bilingualism can be divided into three types, namely: social, cultural and linguistic consequences. The social impact starts from the social life background of the speech participants; cultural consequences depart from the different cultures of the speech participants. Meanwhile, the linguistic result of the mastery of two or more languages possessed by the speech participants, in this case, the Gontor Putra community, causes codemixing, code-switching and borrowing. Code mixing occurs when they use Arabic (BA), English (BIng), Indonesian (BInd), Javanese (BJ), Tolaki (BT), Buginese (BB), Muna (BM), Sundanese (BS), Medan language (BMed), Papuan language (BP).

Another result of mastering two or more languages is code-switching. Code-switching is the process of moving someone from one code to another or from one language to another. Code-switching that occurs in the Gontor Putra speech community is in the form of codeswitching from Arabic to English (BIng), Arabic to Indonesian (BInd), Arabic to Javanese (BJ), Arabic to Tolaki (BT). ), Arabic to Bugis (BB), Arabic to Muna (BM), Arabic to Sundanese (BS), Arabic to Medan (BMed), Arabic to Papuan (BP) and vice versa and transfer code from one variety to another, namely the fushah variety to the ammiyah variety. As explained by (Fauziyah et al., 2019) that the factor that causes code-switching is that the interlocutor has a different language background.

The variations of code-switching that occur in the Gontor Putra speech community with the linguistic repertoire available in the community include: first, code-switching in the form of language translation and second, code-switching in the form of speech level codeswitching. The first type of code transfer comprises: (1) Arabic (BA) to English (BIng), (2) Arabic to Indonesian (BInd), (3) Arabic to Javanese (BJ), (4) Arabic to Tolaki (BT), (5) Arabic to Bugis (BB), (6) Arabic to Muna (BM), (7) Arabic to Sundanese (BS), (8) Arabic to Medan (BMed), (9) Arabic to Papuan (BP) and vice versa. The second type of code transfer includes: (1) from Arabic fushah to Arabic ammiyah and vice versa. Likewise, the case with Arabic fushah to other languages. 


\subsubsection{Pudahoa Code Mixing Variations}

Code mixing is the use of 2 or more languages by inserting one language element into another which is used consistently. Code mixing carried out by the Gontor Putra speech community can be differentiated into code-mixing: (1) in the form of words, (2) in the form of phrases, (3) in the form of the baster, (4) in the form of elements of repetition, and (5) in the form of expressions or idioms. The form of this mixed code in the form of words and baster is determined by considering the form of the lexicon used for Arabic speaking people. If in Arabic speech there is another language lexicon that has an Arabic lexicon view, it means that in the speech there is a mixed code, namely speech spoken by the Gontor Putra speech community in which there is a mixed code speech in the form of words and baster.

The code mix found in Arabic spoken by the Gontor Putra speech community is in the form of a phrase. Mix this code in the form of Indonesian phrases into sentences or language spoken. In Arabic, which is spoken by the Gontor Putra community, there is also a mixed code in the form of a repetition element. Mix code in the form of a clause which means the use of Indonesian in Arabic speaking.

\subsection{The area of using Arabic in the local dialects of Lamomea and Pudahoa}

\subsubsection{Selected Domain of Lamomea Arabic}

The choice of Arabic in the formal domain in the Lamomea Arabic speech community occurs in the classroom from 07.00 - 15.30 and 20.00 - 22.00 through learning activities in all subjects except English and general subjects. Arabic is also used in teacher and student interactions, the use of media and learning resources in the form of Arabic books and curricula. In the formal realm outside the classroom, Arabic is used in announcements, teacher meetings, speech exercises, language courts, visits from Gontor centers, and publication through annual journals. In addition, the formal realm outside the Arabic class is also used in Arabic week (usbu'ullughoh) and English week activities. Other activities in the formal realm outside the classroom are ilqo mufrodat, speeches, debates, ustadzah and santriwati interactions, Kutaib, TV and mufrodat paste. Meanwhile, the use of Arabic in the formal realm of administration is carried out through announcements, pesantren correspondence, committees, writing diplomas and certificates as well as evaluation instruments.

The use of Arabic in family use occurs in the house. Verbal interactions that occur in the realm of the family involve Arabic speech participants, the leaders of the Islamic boarding school, ustadz, ustadzah and santriwati. Meanwhile, the head of the Pondok together with the 
family uses Arabic, Indonesian and local languages. The subject matter discussed in the family use generally relates to important family matters. The subject matter discussed between the leadership, and the santriwati and ustadzah were different from the subject matter discussed between the leader and his family. When viewed from its nature, the main topic of speech discussed between the leadership and students-teacher interaction is formal, and the main topic of speech discussed between the leader and his family is informal.

In the religious realm, Arabic has its position in the religious system. Ritual activities in the Arabic lamomea speech community are forms of religious activity that require special language expression. The uniqueness of Arabic in religious activities is not only due to the importance of smooth communication of information but is more directed to the specific interests of practising one's faith. The use of Arabic in the religious sphere in the Lamomea Arabic speech community occurs not only in the mosque but also includes places that are considered and commonly used for religious activities, including in front of dormitories and halls. Religious activities in the Lamomea Arabic speech community such as recitation, the arrangement of prayer shaf,

The use of Arabic fushah mixed with Indonesian in the religious realm can also be found in the sermons of Eid al-Adha and Eid al-Fitr. The use of the Indonesian language considers the existence of prayer congregations who come from outside the Lamomea Arabic speaking community.

The use of Arabic in the transactional realm occurs in canteens, depots, and cooperatives. The participants in these three places were sellers and buyers. Participants said the sellers came from ustadzah and some staff from the santriwati, while participants said the buyers came from santriwati and walisantri. Generally, their Arabic speaking themed on the sale and purchase of necessities. The use of Arabic in the transactional realm also occurs in shopping centres such as Indomaret and markets. It's just that here code-switching, and code-mixing occurs due to the participation of other communities as speech participants apart from the Lamomea Arabic speaking community. Code-switching and code-mixing that occurs from Arabic to Indonesian or local languages and vice versa. The use of Arabic in the non-formal realm occurs when in the kitchen, field.

\subsubsection{Use of Pudahoa Arabic Dialect}

The choice of Arabic in the formal sphere of the Pudahoa Arabic speech community is the same as the Lamomea Arabic speech community, which occurs in the classroom from 07.00 - 15.30 and 20.00 - 22.00 through learning activities in all subjects except English and 
general subjects. Arabic is also used in the interaction of ustadz and students, the use of media and learning resources in the form of Arabic books and curricula. In the formal use, outside the classroom, Arabic is used in announcements, teacher meetings, speech exercises, language courts, visits from Gontor centres, and publication through annual journals. In addition, the formal realm outside the Arabic class is also used in Arabic week (usbu'ul lughoh) and English week activities. Other activities in the formal realm outside the classroom are ilqo mufrodat, speeches, debates, the interaction of students and teacher, Kutaib, TV and mufrodat tempel. Meanwhile, the use of Arabic in the formal use of administration is carried out through announcements, correspondence, committees, writing diplomas and certificates as well as evaluation instruments.

The use of Arabic in family use occurs in the house. Verbal interactions that occur in the family realm involve Arabic speech participants, the leaders of the Pondok and teacher and students. Meanwhile, the head of the Pondok together with the family uses Arabic, Indonesian and local languages. The subject matter discussed in the family realm generally relates to important family matters. The subject matter discussed between the leadership and the students, and the ustadz was different from the subject matter discussed between the leader and his family. When viewed from its nature, the main topic of speech discussed between the leadership and the santri and ustadz is formal, and the subject matter discussed between the leader, and his family is non-formal.

In the religious realm, Arabic has its position in the religious system. Ritual activities in the Pudahoa Arabic speech community are forms of religious activity that require special language expression. The uniqueness of Arabic in religious activities is not only due to the importance of smooth communication of information but is more directed to the specific interests of practising one's faith. The use of Arabic in the religious realm in the Arabic Pudahoa speech community occurs not only in mosques but also includes places that are considered and commonly used for religious activities, including in front of dormitories and halls. Religious activities in the Pudahoa Arabic speech community such as Friday sermons, recitation, prayer arrangements,

The use of Arabic fushah mixed with Indonesian in the religious realm can also be found in the sermons of Eid al-Adha and Eid al-Fitr. The use of the Indonesian language considers the existence of prayer congregations who come from outside the Pudahoa Arabic speaking community. 


\section{DISCUSSION}

The Arabic language of the Lamomea dialect as a subordinate of the standard language has several functions, namely: (1) as an internal communication tool in the Gontor Putri speaking community, (2) as a symbol of the identity of the local community, (3) as a means of communication in formal, informal and non-formal situations as Ferguson explained that in a region, a relatively stable linguistic situation exists, where in addition to some major dialects (more precisely: main varieties) of one language, other variations can also exist. The main dialects, among which can be standard dialects, or regional standards (Astuti, 2017). Putra (2017) also, describes the diglossia of Arabic pesantren and its influence on regional language defense. Hanafi found that the existence of diglossia Arabic pesantren, which is done consistently, can influence the defense of local language of speech in pesantren.

On discussion code-switching, the result of mastering two or more languages is codeswitching. Code-switching is the process of moving someone from one code to another or from one language to another. Code-switching occurred in the Gontor Putri speech community is in the form of code-switching from Arabic to English, Arabic to Indonesian, Arabic to Javanese, Arabic to Tolaki, Arabic to Bugis, English to Arabic, Indonesian to Arabic, Javanese to Arabic, Tolaki to Arabic, Bugis to Arabic, and vice versa as well as codeswitching from one variety to another, namely the fushah variety to the ammiyah variety. Aviah et al. (2019) explains that code-switching occurs between languages, between variations, or styles in a language. As explained by Kholidah and Haryadi (2017) regarding the speech code of Aceh students that the form of speech code choice for Acehnese students used in the socialization in Semarang is in the form of a single language, including nonformal Indonesian, Ngoko Javanese, and Acehnese languages; code-switching; and mix code. Aceh students in Semarang tend to talk about code-switching. This is caused by using language from different speakers.

Other research by Rohmani et al. (2013) examines the form of code-switching and codemixing, the factors causing code-switching and code-mixing, and the functions of codeswitching and code-mixing in Negeri 5 Menara novel by Ahmad Fuadi. Rohmani found: First, the code-switching phenomena are established in the four formation. The code-mixing phenomena are established in the seven formations. Second, the factors supporting codeswitching are related to the speaker and speaker personality, speech partner, speech function and objective, and speech situation. The factors supporting code-switching includes extralinguistic and intralinguistic. Extralinguistic factor relates to the characteristics of the speaker such as social background, religiosity feeling, education level, and locality feeling. 
Intralinguistics factor relates to the absence of words in a language that can accommodate the concept of meaning intended in the linguistic element inserted. And third, the functions of code-switching and code mix in Negeri 5 Menara novel by Ahmad Fuadi are to explain, to command, to pray, to ask a question, and to confirm the intention.

Ala et al., (2019) explains that code-mixing is a state of mixing two languages or two or more languages without anything demanding that mixing. There are mixed codes found in Arabic spoken by the Gontor speech community in the form of phrases. Mix this code in the form of Indonesian phrases into sentences or language spoken. In Arabic spoken by the Gontor speech community, there is also a code mix in the form of a looping element. Mix code in the form of a clause which means the use of Indonesian in Arabic speech. Azzuhri (2016) describe in Language and Local Wisdom: Social Harmonization of the Arab-Javanese Community in Kampung Arab found several findings. First, in the communication process, there is a change of words in two different languages alternately. For example, an ethnic Javanese asks an Arab ethnic using the Arabic word, then an Arab ethnic answers it in Javanese, and vice versa. The local Arabic words used by the Javanese ethnic are Arabic convention words. Second, the majority of the people were of Javanese and Arabian descent, and some were of Chinese descent. They used mixed language between Arabic and Javanese language for their daily communication. The Arabian and Javanese people in Klego lived in harmony with the existed local wisdom.

On the discussion about the area of using Arabic in the local dialects of Lamomea and Pudahoa, the realm of using Arabic in local dialects consists of the formal domain, the family domain, the religious domain, the transactional realm, the social sphere, the informal sphere and the non-formal domain. As explained by Tiawaldi and Wahab (2017) that Arabic is a dynamic language, so it changes from time to time. Changes can occur in the linguistic area and can occur in the realm of phonology. On another discussion, Oetomo in Sumarsono and Partana (2007) examines the theme of language and identity in the Chinese group in Pasuruan by observing their daily speech in various speech events, for example in the dentist room, in the hospital, at the house of a person whose family member has died, in stores and so on. Research suggests that language can also influence groups. Oetomo concluded that Chinese society could be grouped into Totok Chinese and Peranakan Chinese. This shows that the language can reflect group identity.

The relation pattern of the use of Arabic with situations and conditions causes differences in the variety of different languages. As explained by Muhandis (2014) when photographing the relationship between Arabic and social strata in Pekalongan, there is a difference in the 
use of Arabic at different social strata in society. Wahyuningsih and Kaharuddin (2019) also found about Regional Language Interference and Indonesian Language Against the Use of Arabic. She has found the causes of interference are as follows: first; bilingualism of the speech participants, second; thin loyalty of the recipient's language users, third; insufficient vocabulary of the recipient's language in the face of progress and renewal, fourth; the disappearance of words that are rarely used, and fifth; the need for synonyms. At the same time, the form of Arabic language interference is; Cultural interference, sexual interference, semantic interference, syntactic interference, ontological interference, symphological interference, paralinguistic interference.

Furthermore, Azzuhri (2012) analyzes the linguistic amalgamation among Arabian and Javanese inhabitants of Klego Pekalongan. The results showed the form of linguistics convention in communication, based on linguistics rule (derivation and lexicon) and this convention contributed toward social harmonization among both of them. The indication of linguistics convention revealed from the compatibility and incompatibility of linguistics rule (derivation and lexicon). The convention took place and diffused peacefully among Arabic and Javanese (linguistic acculturation), so it's pretty hard to distinguish between Arabic Descent and Javanese Descent in Klego in oral communication. Nida'uljanah and Ridwan (2018) also, research Sociodialectology Study of Hadramiy Community Language (Case Study of Indonesian Society of Arab Descent in Pasar Kliwon Surakarta). She has fouds: first, Pasar Kliwon'n language has a historical relationship to the Arabic language. The research finds 136 couple words that have a genetic relationship among 200 Swadesh used vocabularies or $68 \%$ among them. It clear to be concluded that the relationship occurred between two variants of that language. Second, the separating time of language was predicted taking place from 1011 to 1207 . Wekke (2016) also explains about relating the Arabic learning environment and the character construction of the students. Wekke found during a process of teaching and learning, santri (student) will have some behavior to master the language. wekke shows that the Arabic language learning conducted in the environment surrounding pesantren (boarding school) as a source of learning. It will function as a medium as well. Besides, those activities will benefit shortly for the contextual of living in society. Finally, as the premier program, the Arabic language will expand students' skills and confidence to explore the Islamic horizon of knowledge.

Thus, the use of Arabic in the Pudahoa Arabic speech community is not much different from the Lamomea speech community. The difference lies in the types of social attributes of the speech participants. Generally, Pudahoa Arabic speech participants are all ustadz and 
santri so that the language atmosphere tends to follow the social and language attributes of men and vice versa, all participants in Arabic Lamomea speech except ustadz, the linguistic atmosphere tends to follow the social and language attributes of women. And this was also followed by the adjustment of the domains of Arabic use.

\section{CONCLUSION}

Based on the findings and discussions, it can be concluded that: This study found: first, the Arabic variation used in social interactions in Gontor Putri 4 is Arabic in the Lamomea dialect. Meanwhile, the Arabic variation used in social interactions in Gontor Putri 7 is Arabic in the Pudahoa dialect. The Arabic languages of the Lamomea and Pudahoa dialects have the same position as the Arabic fushah and ammiyah varieties that have developed in various regions that use these two languages. The variations of code-switching that occur in the speech communities of Gontor Putri 4 and Gontor Putra 7 with the linguistic repertoire that exists in the community include: (1) code-switching in the form of language translation and (2), code-switching in the form of speech level code-switching. And furthermore, the codes found in Arabic spoken by the Gontor Putri 4 and Putra 7 speaking community are in the form of phrases. Mix this code in the form of an Indonesian phrase into a sentence or speech. In Arabic, which is spoken by the community, Gontor said there is also a mixture of codes in the form of elements of repetition. Second, the Pudahoa Arabic dialect is the same as the Lamomea dialect. Pudahoa dialect Arabic as a subordinate standard language has several functions, namely: (1) as a means of internal communication in society, (2) as a symbol of the identity of the local community, (3) as a means of communication. informal situations. Third, the use of Arabic in the local dialects of Lamomea and Pudahoa consists of the formal domain, kinship domain, religious domain, transactional use, social environment, informal environment, and non-formal domain. The use of Arabic in the Lamomea dialect and the Pudahoa dialect has the same characteristics, that is, it occurs in the formal use in the classroom, outside the classroom and administrative management, in the family realm it occurs in the home, in the religious realm it occurs in recitation and worship activities, in the transactional realm it occurs in canteens and cooperatives, in the non-formal realm it occurs when in the kitchen, field, bathrooms, dormitories, and alumni.

It is realized that this research is limited by the strict conditions and procedural rules in Pesantren Gontor, therefore the depth of the variables studied is not maximal. In particular, this research does not reveal how the interplay between Arabic and the culture of the local 
community. The author hopes that there will be further research that focuses on how patterns of influence between Arabic and local culture.

\section{REFERENCES}

Ala, M. M., Miftahuddin, A., \& Qutni, D. (2019). Interferensi fonologis dan gramatikal siswa kelas VII MTs N 1 Kudus dalam pembelajaran bahasa Arab (kajian sosiolinguistik). Journal of Arabic Learning and Teaching, 8(1), 84-94. https://doi.org/10.15294/la.v8i1.32549

Astuti, W. (2017). Diglosia masyarakat tutur pada penggunaan bahasa Arab (Kajian kebahasaan terhadap bahasa Fusha dan bahasa 'Amiyah dilihat dari perspektif sosiolinguistik). Jurnal Komunikasi Dan Pendidikan Islam, 6(2), 143-161. https://doi.org/10.36668/jal.v6i2.29

Aviah, N., Kuswardono, S., \& Qutni, D. (2019). Alih kode, campur kode dan perubahan makna pada integrasi bahasa Arab dalam bahasa Indonesia di film "Sang Kiai" (analisis sosiolinguistik). Lisan Al-Arab: Journal of Arabic Language And Arabic Teaching, 8(2), 135-139. https://doi.org/10.15294/la.v8i2.36169

Azzuhri, M. (2012). Konvensi bahasa dan harmonisasi sosial: Telaah linguistik dalam percakapan campur bahasa Arab - Jawa dan kontribusinya terhadap harmonisasi sosial di masyarakat "Kampung Arab" Klego - Pekalongan. Jurnal Penelitian, 8(1), 37-56. https://doi.org/10.28918/jupe.v8i1.41

Azzuhri, M. (2016). Bahasa dan kearifan lokal: Harmonisasi sosial masyarakat Arab - Jawa di kampung Arab. Arabi : Journal of Arabic Studies, 1(2), 90. https://doi.org/10.24865/ajas.v1i2.28

Fajaruddin, S. (2011). Analisis prinsip kerja sama Grice dalam naskah drama Dr. med.hiob. Prätorius karya Kurt Goetz. Fakultas Bahasa dan Seni Universitas Negeri Yogyakarta.

Fasold, R. W. (1991). The sociolinguistics of society. Wiley-Blackwell.

Fauziyah, A., Itaristanti, I., \& Mulyaningsih, I. (2019). Fenomena alih kode dan campur kode dalam angkutan umum (Elf) Jurusan Sindang Terminal_Harjamukti Cirebon. SeBaSa: Jurnal Pendidikan Bahasa Dan Sastra Indonesia, 2(2), 79-89. http://ejournal.hamzanwadi.ac.id/index.php/sbs/article/view/1334

Ferguson, C. A. (1997). Grammatical agreement in classical Arabic and the modern dialects. In Structuralist Studies in Arabic Linguistics (pp. 81-91). BRILL. https://doi.org/10.1163/9789004348578_010

Hymes, D. H. (2003). Foundations in sociolinguistics: An ethnographic approach. Psychology Press.

Kholidah, U., \& Haryadi, H. (2017). Wujud pilihan kode tutur mahasiswa Aceh pada ranah pergaulan di Semarang. Seloka: Jurnal Pendidikan Bahasa Dan Sastra Indonesia, 6(2), 208-217. https://doi.org/10.15294/SELOKA.V6I2.17288

Kurniasih, D., \& Zuhriyah, S. A. (2017). Alih kode dan campur kode di pondok pesantren mahasiswa Darussalam. Indonesian Language Education and Literature, 3(1), 53-65. https://doi.org/10.24235/ileal.v3i1.1521

Ma’u, J. A. R. Z., Fajaruddin, S., Lamahala, C. B. M., Fuadi, C., Perdana, S., \& Aryanto, A. (2019). Submissiveness and resistance: Different paradigm between Indonesian language and English. LingTera, 6(1). https://doi.org/10.21831/LT.V6I1.23966

Muhandis, M. (2014). Relasi bahasa arab dengan strata sosial masyarakat dan implikasinya terhadap kehidupan sosial, ekonomi, politik dan agama (Kajian sosiolinguistik pada 
masyarakat tutur Arab Keturunan di Kelurahan Kauman Pekalongan Timur). Jurnal Penelitian, 10(2), 313-335. https://doi.org/10.28918/jupe.v10i2.366

Mustikawati, D. A. (2014). Alih kode dan campur kode antara penjual dan pembeli (Analisis pembelajaran berbahasa melalui studi sosiolinguistik). Jurnal Dimensi Pendidikan Dan Pembelajaran, 2(2), 23-32. https://doi.org/10.24269/dpp.v2i2.154

Nida'uljanah, H., \& Ridwan, M. (2018). Kajian sosiodialektologi bahasa masyarakat Hadramiy (Studi kasus masyarakat Indonesia Keturunan Arab di Pasar Kliwon Surakarta). Jurnal CMES, 10(2), 181. https://doi.org/10.20961/cmes.10.2.20208

Pride, J. B., \& Holmes, J. (1972). Sociolinguistics: Selected readings. Penguin Books.

Putra, W. H. (2017). Diglosia bahasa Arab pesantren dan upaya pemertahanan bahasa daerah. QALAMUNA: Jurnal Pendidikan, Sosial, Dan Agama, 9(02), 47-70. https://doi.org/10.37680/qalamuna.v9i02.366

Rohmani, S., Fuady, A., \& Anindyarini, A. (2013). Analisis alih kode dan campur kode pada Novel Negeri 5 Menara karya Ahmad Fuadi. BASASTRA Jurnal Penelitian Bahasa, Sastra Indonesia Dan Pengajarannya, 2(1), 1-16.

Sumarsono, S., \& Partana, P. (2007). Sosiolinguistik. Sabda bekerjasama dengan Pustaka Pelajar.

Sutarsih, A. (2016). Campur kode dari bahasa ke dalam bahasa Indonesia tuturan Masyarakat Keturunan Arab di Kampung Pekojan Semarang. Widyaparwa, 44(2), 73-84. https://doi.org/10.26499/wdprw.v44i2.137

Tiawaldi, A., \& Wahab, M. A. (2017). Perkembangan bahasa Arab modern dalam perspektif sintaksis dan semantik pada Majalah Aljazeera. Arabiyat: Jurnal Pendidikan Bahasa Arab Dan Kebahasaaraban, 4(1), 1-19. https://doi.org/10.15408/a.v4i1.5328

Wahab, L. A. (2012). Pilihan bahasa masyarakat keturunan Arab: Studi sosiolinguistik di perkampungan Arab Empang Bogor. Universitas Negeri Jakarta.

Wahab, L. A. (2015). Pilihan bahasa pada komunitas tutur pasar Baruga. Al-Izzah: Jurnal Hasil-Hasil Penelitian, 10(2). https://doi.org/10.31332/ai.v10i2.342

Wahyuningsih, S., \& Kaharuddin, K. (2019). Interferensi bahasa daerah dan bahasa Indonesia terhadap penggunaan bahasa Arab. Al-Af'idah : Jurnal Pendidikan Bahasa Arab Dan Pengajarannya, 3(2), 90-100. http://ejournal.iaimbima.ac.id/index.php/afidah/article/view/336

Wekke, I. S. (2016). Lingkungan belajar bahasa Arab dan konstruksi karakter santri: Tinjauan pesantren minoritas Muslim. Al-Lisan: Jurnal Bahasa, 1(2), 49-76. https://www.journal.iaingorontalo.ac.id/index.php/al/article/view/320

Zaini, H. (2010). Perubahan makna leksikal dalam pemakaian bahasa Arab. Adabiyyāt: Jurnal Bahasa Dan Sastra, 9(1), 134-153. https://doi.org/10.14421/ajbs.2010.09107 